\title{
Developmental differences in the expression of the cholera toxin sensitive subunit (Gs $\alpha$ ) of adenylate cyclase in the rat small intestine
}

\author{
I R Sanderson, Z Xu, S W Chu, Q Y Xie, L J Levine, W A Walker
}

\begin{abstract}
Background-The stimulatory guanosine triphosphate (GTP) binding protein $\alpha$ subunit $(\mathrm{Gs} \alpha)$ of adenylate cyclase is the target protein for cholera toxin.

Aims/methods-The expression of this signal transducer was analysed in the small intestine of developing rats by RNA transfer (northern blot) analysis by immunoblotting, and by ADP-ribosylation of membrane proteins.

Results-Intestinal Gs $\alpha$ mRNA (about 1.9 kb) was increased in the neonate compared with the adult rat. Two isoforms of Gs $\alpha$ proteins, a 45000 and a 52000 form, were expressed in the small intestinal epithelial cell and both were ADP-ribosylated by cholera toxin. A significant increase in the larger isoform (52 000) and in its ribosylation was noted in the 2 week old suckling compared with post-weaned older animals. The protein content or ribosylation of the smaller form (45000) did not significantly change with age.

Conclusion-These data show that a developmental decline of intestinal Gs $\alpha$ expression seems to be, in part, regulated at the mRNA level. An increased Gs $\alpha$ expression in the immature intestine may help to explain a previously reported, dose dependent increased adenylate cyclase response and an increase in fluid secretion to cholera toxin in neonates compared with adults.
\end{abstract}

(Gut 1996; 38: 853-858)

Developmental

Gastroenterology

Laboratory, Combined

Program in Pediatric

Gastroenterology and

Nutrition, The

Massachusetts General

Hospital and Harvard

Medical School,

Boston, USA

I R Sanderson

$\mathrm{ZXu}$

$S$ W Chu

Q Y Xie

L J Levine

W A Walker

Correspondence to: Dr I R Sanderson,

Developmental

Gastroenterology

Laboratory, Cogy

Laboratory, Combined

Program in Pediatric

Gastroenterology and.

Nutrition, Massachusetts

149 13th Street (149-3404)

149 13th Street (149.

Charlestown, MA

02129-2060, USA.

Accepted for publication

13 December 1995
Keywords: Gs $\alpha$ subunit, development, cholera toxin, ADP-ribosylation.

The signal transducing guanosine triphosphate (GTP) binding protein (G protein) that regulates adenylate cyclase (EC 4.5.1.1) is an $\alpha \beta \gamma$ heterotrimer. ${ }^{2}$ Under physiological conditions, the binding of a hormone or neurotransmitter to the cell surface $\beta$-adrenergic receptor activates Gs, the stimulatory regulator of adenylate cyclase. The activation is initiated by a release of bound GDP and the subsequent binding of GTP to the Gs $\alpha$ subunit of Gs. Gs $\alpha$ bound to GTP dissociates from the $\beta \gamma$ subunit to yield an active Gs $\alpha-G T P$ form, which is directly responsible for activation of the cyclase catalytic unit. Hydrolysis of bound GTP to GDP by the GTPase intrinsic to Gs $\alpha$ terminates the signal.

During infection, cholera toxin (CT) is produced in the upper small intestine by Vibrio cholerae. The interaction of this toxin with the enterocyte results in a toxigenic diarrhoeal disease that principally affects young children. ${ }^{3}$ $\mathrm{CT}$ is an ADP-ribosylating toxin that uses Gs $\alpha$ as its substrate. ${ }^{4}$ It is an oligomeric protein of 84000 , composed of one A-subunit (active component) associated non-covalently with five B-subunits (binding components). The $\mathrm{A}$ subunit contains two polypeptides, denoted $A_{1}$ and $A_{2}$, linked by a single disulphide bond. The CT B-subunit binds to a GM1 glycolipid receptor on the enterocyte surface, and the A-subunit disassociates from $\mathbf{B}$ and enters into the cell, presumably via the formation of endosomes. ${ }^{5}$ Cleavage of $A_{2}$ from the A-subunit, by a still undefined cellular reaction, activates the ADP-ribosyltransferase of $A_{1}$. The enzyme activity of $A_{1}$ is further increased by another cellular factor, namely ADPribosylation factor (ARP). ${ }^{6}$ The activated $\mathrm{A}_{1}$ then catalyses ADP-ribosylation of $G s \alpha,{ }^{14}$ which in turn inhibits GTPase activity that acts to interrupt the conversion of an active $\alpha$-GTP form to an inactive form. As a result, adenylate cyclase is persistently activated to produce cAMP from ATP. Cyclic AMP accumulation subsequently opens the $\mathrm{Cl}^{-}$channel in intestinal crypt cells, and inhibits the $\mathrm{NaCl}$ co-transporter in intestinal villus cells, resulting in a changed ion flux that causes massive diarrhoea. ${ }^{7}$ Recent studies show that the CFTR (cystic fibrosis transmembrane conductance regulator) itself could be the cAMP-responsive chloride channel ${ }^{89}$ and it is proposed that patients with cystic fibrosis may be less susceptible to CT induced diarrhoea. ${ }^{1011}$

The human Gs $\alpha$ gene protein on human chromosome 20 contains 13 exons and 12 introns and spans about $20 \mathrm{~kb} .{ }^{12}$ In the coding region, the nucleotide sequence homology between human and rat Gs $\alpha$ is $95 \% .{ }^{13}$ The tissue specific expression of the Gs $\alpha$ isoform results from an alternative splicing of a single mRNA precursor. In the human brain, Gs $\alpha$ protein exists predominantly as both a small (45 000) and large (52 000) protein, which can be ADP-ribosylated. ${ }^{14}$ In the rabbit intestine, CT catalyses the ADP-ribosylation of proteins of 40 and 47000 respectively. ${ }^{9}$ The proportion of these isoforms varies among tissues and cells and their functional differences have not yet been clarified.

Despite recent extensive studies of G protein, little is known about the gene expression and regulation of Gs $\alpha$ in the enterocyte, the natural target cell for CT during development. Previously, we have reported an increase in adenylate cyclase activity ${ }^{15}$ and in fluid 
secretion ${ }^{16}$ in the small intestine of suckling rats compared with older animals. We have hypothesised that a variation in amounts of Gs $\alpha$ protein during intestinal development might be one of the factors that contributes to this changed host responsiveness. To test this hypothesis, we have studied the ontogeny of Gs $\alpha$ expression in the rat small intestine. Our results show that there is indeed an age dependent decline in intestinal Gs $\alpha$ mRNA expression, protein concentration, and ribosylation during development. Accordingly, we have concluded that an increase in gene expression for Gs $\alpha$ in the immature gut may contribute, in part, to the increased enterocyte responsiveness to CT in young mammals. ${ }^{11}$

\section{Methods}

Animals

Spraque-Dawley rats (Charles River Breeding Laboratories, Wilmington, MA) were housed in an animal room with a 12 hour light/dark cycle, fed rat chow (Purina, St Louis, MO), and permitted water ad libitum. In all studies, animals remained with their mothers until 2 weeks when one half of each litter was removed for separation of epithelial cells. The remaining animals were weaned at 3 weeks and examined at 8 weeks. For mRNA studies, four litters of 10 pups each were examined, litters being split at 2 weeks with five pups removed from each litter. Differences in Gs $\alpha$ protein were examined in a separate litter and a further litter was used to study differences in ribosylation. All experiments were approved by the Subcommittee on Research Animal Care at the Massachusetts General Hospital.

\section{Enterocyte isolation}

Enterocytes were isolated from full length rat small intestine according to a modification of a method described by Weiser. ${ }^{17}$ A protease inhibitor PMSF ( $1 \mathrm{mM}$ final concentration) was added to all buffers. Intestinal sacs were filled with the buffer and incubated at $4^{\circ} \mathrm{C}$. Enterocytes from postweaned rats were collected every 20 minutes for four consecutive periods and pooled. The collecting time was reduced to 15 minutes for neonatal enterocytes. For studies of Gs $\alpha \mathrm{mRNA}$, isolated enterocytes were homogenised in guanidinium salts. For protein preparations, enterocytes were transferred to homogenising buffer (see later).

\section{Nucleic acid probes}

Hybridisation experiments were performed using (1) Gs $\alpha$ : cDNA for Gs $\alpha$ was made from the polymerase chain reaction (PCR) products of reverse transcription of rat epithelial cell mRNA using Gs $\alpha$-specific oligonucleotides as primers. Primers were synthesised from published sequences Genbank M12673. ${ }^{12}{ }^{13}$ After reverse transcription using $50 \mathrm{U} / \mu \mathrm{l}$ of reverse transcriptase, cDNA was amplified in four separate reaction tubes with each combination of the following upstream primers (Gsa 331s: CAGCTGCAGA AGGACAAGCA; Gsa 483s: TGCAAGGAGC AACAGCGATG) and downstream primers (Gsa 849as: CGTCCTGACC TCTGGAATCT; Gas 931as: GATGAACGCC GCAAGTGGAT). The size of four PCR products was as predicated by the distance between the primers. Confirmation of their identity was obtained by transferring DNA to nylon membranes (Southern blot) and hybridising with a separately synthesised 39-base oligonucleotide Gs $\alpha$ probe (DuPont/NEN, Boston, MA). (2) $\gamma$-actin: cDNA as a BamHI/HindIII insert in a pSP64 vector (a gift of Dr Herman Eisen, Massachusetts Institute of Technology, Cambridge, MA). ${ }^{18}$ DNA was labelled with [32 P]dCTP $(3000 \mathrm{Ci} / \mathrm{mmol}$, DuPont $/ \mathrm{New}$ England Nuclear, Boston, MA) with Klenow fragment after random hexanucleotide priming ${ }^{19}$ using Prime-It II labelling system (Stratagene, Anaheim, CA).

\section{$R N A$ transfer (northern blot analysis)}

The epithelial cell pellet was dissolved into at least 20 vol GIT buffer (4 M guanidine isothiocyanate, $50 \mathrm{mM}$ TRIS ( $\mathrm{pH} 7 \cdot 6$ ), $2 \%$ Sarkosyl and $100 \mathrm{mM}$ 2-mercaptoethanol). The RNAs were deproteinised by selective precipitation from GIT buffer and by extraction with phenol, chloroform, and isoamyl alcohol. ${ }^{20-22}$ RNA was quantified by absorbance at $260 \mathrm{~nm}$ and stored at $-20^{\circ} \mathrm{C}$. For RNA transfer blots (northern blots), RNAs ( $5 \mu \mathrm{g}$ per well) were separated in morpholinopropane sulphonic acid-formaldehyde agarose gels ${ }^{2324}$ and transferred to GeneScreen Plus membranes (DuPont/NEN) by capillarity. Blots were hybridised and washed according to manufacturer's recommendations (DuPont/NEN). Washed blots were autoradiographed between intensifying screens at $-70^{\circ} \mathrm{C}$. The amount of hybridisation of labelled Gs $\alpha$ chain cDNA to RNA transfer blots was determined by measuring the optical density of the Gs $\alpha$ mRNA by scanning the autoradiographs utilising Molecular Dynamics (Molecular Dynamics, laser densitometer Sunnyvale, CA) as described later. Once Gs $\alpha$ had been measured blots were reprobed with $\gamma$-actin whose expression does not change with development in epithelial cells. The amount of Gs $\alpha$ mRNA of the intestinal epithelium of each individual rat was expressed as the ratio of Gs $\alpha$ mRNA optical density to $\gamma$-actin mRNA optical density. RNA samples from any one litter were always electrophoresed, transferred, probed, and measured together as a single unit. RNA from different litters were examined on different membranes. It is possible therefore to examine the changes in Gs $\alpha$ within a litter, but absolute values cannot be compared between litters.

\section{Enterocyte protein preparations}

All procedures were performed at $4^{\circ} \mathrm{C}$. Isolated enterocytes were homogenised in a homogenising buffer $(0 \cdot 1 \mathrm{M}$ TRIS- $\mathrm{HCl}, \mathrm{pH}$ 
A

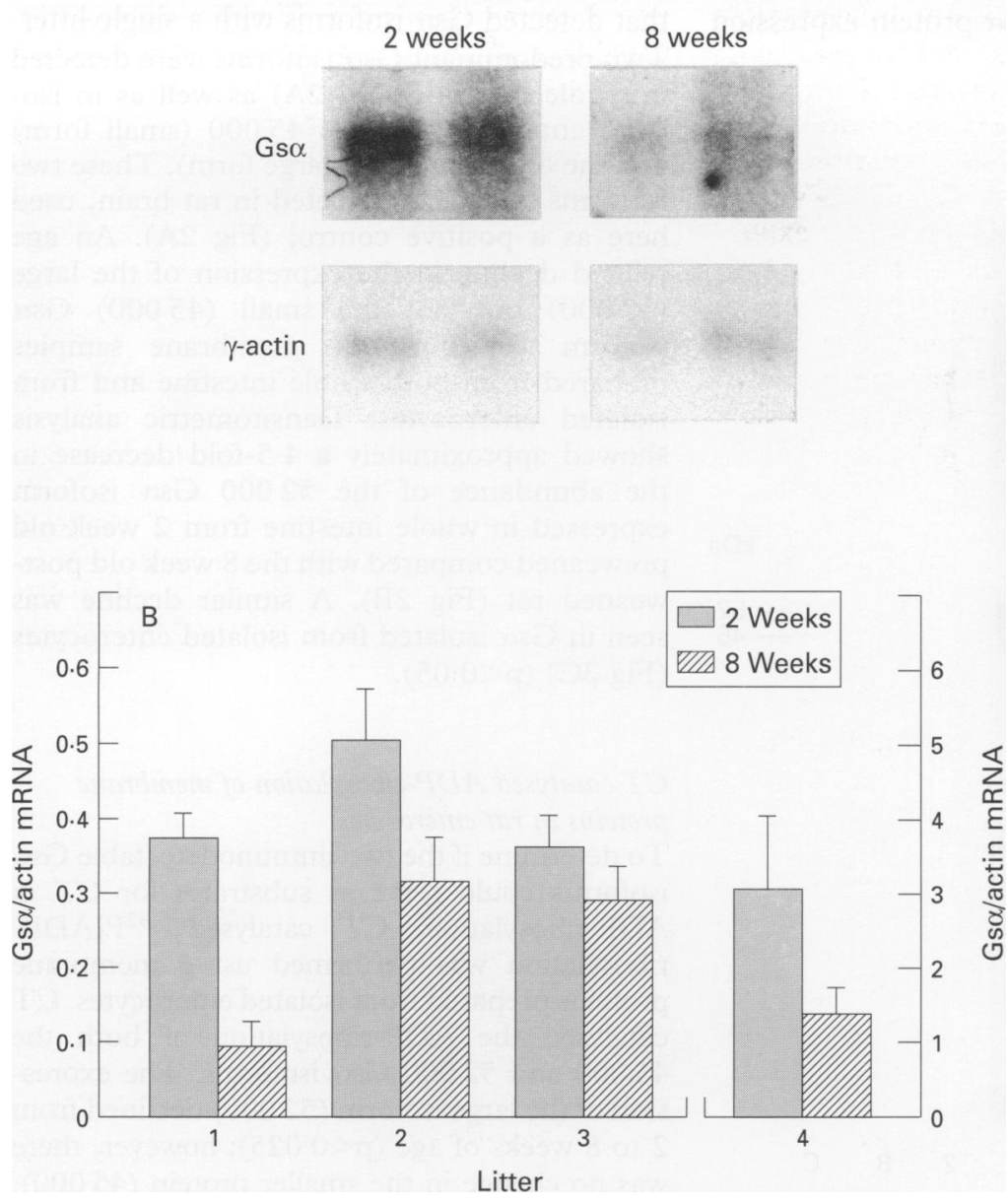

Figure 1: RNA transfer blot analysis of Gs $\alpha m R N A$ expression in the rat small intestine during perinatal development. (A) Northern blot of epithelial cell $R N A$ probe with $G s \alpha$ and $\gamma$-actin cDNA showing a reduction in Gs $\mathrm{mRNA}$ ratio in small intestinal epithelial cells of rats between 2 weeks and 8 weeks (from a single litter). Five $\mu g$ of RNA from each animal was electrophoresed and transferred to nylon membranes. (B) The blots were hybridised with $G s \alpha$ and $\gamma$-actin cDNAs sequentially and the degree of hybridisation measured by densitometry. Each individual transfer blot contained all the specimens of a single litter at both time points. The ratio of the Gs $\alpha$ and $\gamma$-actin for each rat was calculated. The data are expressed as mean (SEM) of the Gs $\alpha$ mRNA to $\gamma$-actin mRNA ratios. Gsa/actin $m R N A$ was significantly greater $(p<0.05)$ in suckling animals than in 8 week rats. bands were quantified using a laser densitometer (Molecular Dynamics, Sunnyvale, CA). The densitometry programme was established to subtract for background, which was recorded before other measurements. The optical density of bands relative to protein content was verified in other experiments using radioactive probes, where direct measurements of radioactivity correlated with densitometry. ${ }^{27}$

\section{ADP-ribosylation of proteins with CT}

Membrane fractions prepared from isolated neonatal and adult enterocytes and adult brain homogenates were used. CT catalysed ADPribosylation was performed as described by Gill and Woolkalis. ${ }^{28}$ The reaction mixture contained $100 \mu \mathrm{g}$ of membrane, $20 \mu \mathrm{g} / \mathrm{ml}$ of activated CT, $20 \mu \mathrm{M}$ [ $\left.{ }^{32} \mathrm{P}\right] \mathrm{NAD} \quad(20000$ $\mathrm{cpm} / \mathrm{pmol}$ ), $20 \mathrm{mM}$ isoniazid, $1 \mathrm{mM} 3-$ acetylpyridine adenine nucleotide, $10 \mathrm{mM}$ thymidine, $10 \mathrm{mM}$ dithiothrietol, $0 \cdot 1 \%$ Triton $\mathrm{X}-100$, and $0.5 \mathrm{mM} \mathrm{Gpp}(\mathrm{NH}) \mathrm{p}$. The reaction was incubated at $25^{\circ} \mathrm{C}$ for one hour. The membrane was recovered and subjected to SDSPAGE on $10 \%$ gel. The gel was dried and subjected to autoradiography. Ribosylation of each isoform was determined by measuring densitometry of bands at the appropriate molecular weight on the autoradiograph.

\section{Statistics}

mRNA expression was examined by analysis of variance (ANOVA). The effects of age and litter on Gs $\alpha /$ actin mRNA were examined as independent variables. Differences were regarded as significant at $\mathrm{p}<0 \cdot 05$. Gs $\alpha$ protein experiments were all performed within one litter and the results of the change between 2 weeks and 8 weeks were compared using Student's $t$ test. Similarly ribosylation was also examined within a single litter. In these latter cases each point represents the mean and standard deviation of three experiments.

\section{Results} tinin, and $10 \mu \mathrm{g} / \mathrm{ml}$ leupeptin as protease inhibitors. After centrifugation of the homogenate at $3000 \mathrm{~g}$ for 15 minutes, the supernatant was centrifuged at $105000 \mathrm{~g}$ for one hour. The resulting pellet was resuspended in homogenising buffer and saved for immunoblotting and ADP-ribosylation experiments. A particulate fraction was also prepared from adult rat brain and used as a positive control.

\section{Gel electrophoresis and immunoblotting}

Membrane proteins were subjected to SDSPAGE on a $10 \%$ gel, ${ }^{25}$ transferred to a nitrocellulose membrane, ${ }^{26}$ and probed with a rabbit anti-G protein $(\mathrm{RM} / \mathrm{G} \mathrm{G} \alpha)$ polyclonal antibody. The blot was subsequently incubated with a horseradish peroxidase conjugated donkey antirabbit immunoglobulin polyclonal antibody. The target proteins were then detected with an enhanced chemiluminescence western blotting system as described by the supplier (Amersham, Arlington Heights, IL). Protein
Developmental decline in Gs $\alpha m R N A$ expression To examine the effect of age on Gs $\alpha$ mRNA, four litters (40 pups) were examined. Twenty pups were killed at 2 weeks of age and the intestinal epithelial cell fraction of each animal was examined separately. The remaining 20 were weaned at 3 weeks and examined at 8 weeks. Hybridisation was observed at a band that corresponded to $1.9 \mathrm{~kb}$, the size of $\mathrm{Gs} \alpha$ mRNA (Fig 1A). Northern blot analysis of Gs $\alpha$ mRNA $/ \gamma$-actin mRNA from epithelial cells showed a significant decrease with age between 2 and 8 weeks $(p<0.05)$ (Fig 1$)$. Although each litter showed a reduction in Gs $\alpha$ RNA in relation to that of $\gamma$-actin, there was a variation in the degree of this effect between litters, being $74 \%, 38 \%, 20 \%$, and $54 \%$ in litters 1 to 4 , respectively. The amount of $\gamma$-actin mRNA per cell is known to remain constant in intestinal epithelial cells during development. ${ }^{24}$ 
Expression patterns of $G$ s $\alpha$ isoforms in the developing rat intestine

To identify intestinal Gs $\alpha$ and to determine if there was a decline in Gs $\alpha$ protein expression

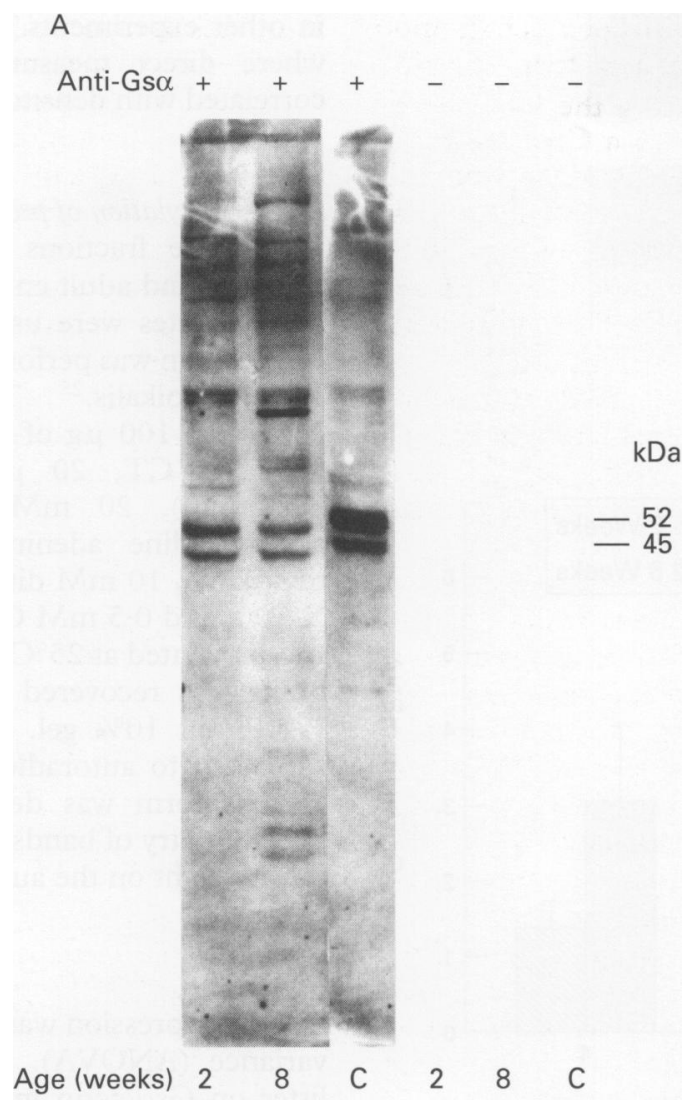

Figure 2: Gs $\alpha$ protein expression in whole intestine and isolated enterocytes. (A) The membrane fraction for whole intestine (50 $\mu \mathrm{g}$ proteinlane) of 2 week and 8 week old and brain (C) from adult rats were subjected to SDS-PAGE transferred to nitrocellulose filter, and probed with anti-G protein (RM1 Gsa) polyclonal antibody. (B) Densitometric analysis of western blot $(A)$ for whole intestine performed in three separate experiments, as expressed as mean (SD). (C) Densitometric analysis of $G$ s $\alpha$ protein from enterocytes isolated for 2 and 8 week old rats (see methods). Membrane fractions were examined as for whole intestine. Results show mean (SD) of three separate experiments. * Significantly different at the $p<0.05$ level from the value in the 8 week rat.

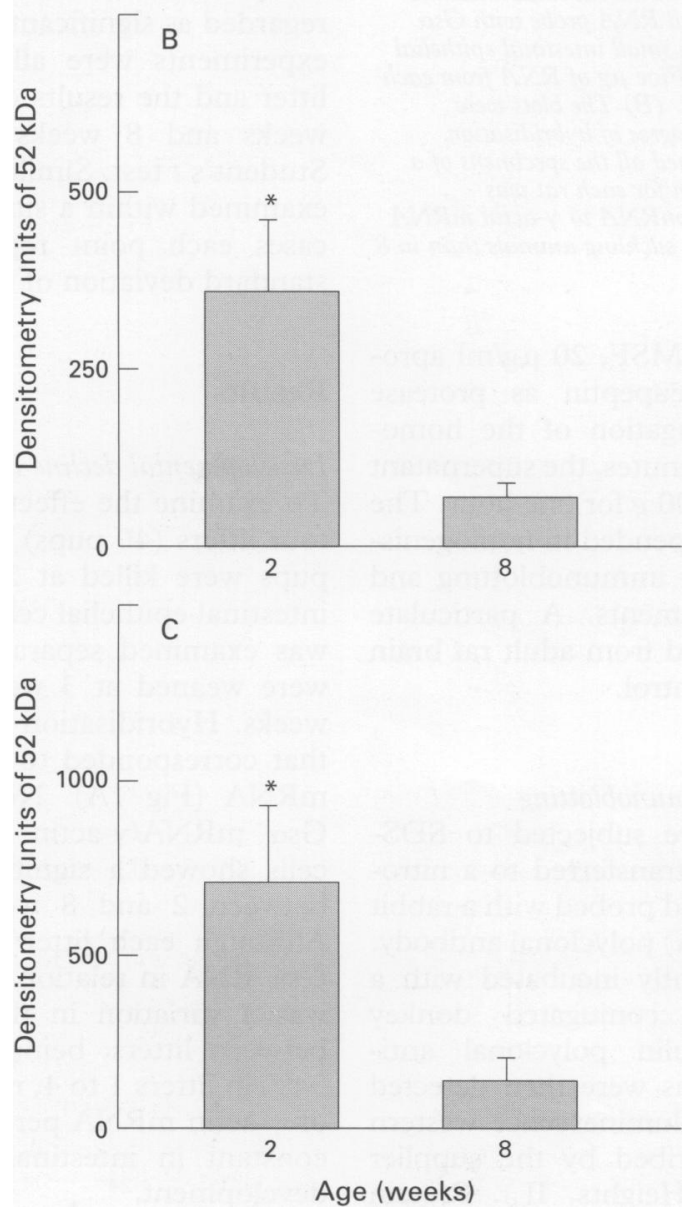

as noted with Gs $\alpha$ mRNA during development, intestinal membrane samples were analysed by immunoblotting using an antibody that detected Gs $\alpha$ isoforms with a single litter. Two predominant $\mathrm{Gs} \alpha$ isoforms were detected in whole intestine (Fig 2A) as well as in isolated enterocytes, one a 45000 (small form) and the other a 52000 (large form). These two isoforms were also detected in rat brain, used here as a positive control (Fig 2A). An age related decline in the expression of the large (52 000) but not the small (45000) Gs $\alpha$ isoform was noted in membrane samples prepared from both whole intestine and from isolated enterocytes. Densitometric analysis showed approximately a $4 \cdot 5$-fold decrease in the abundance of the $52000 \mathrm{Gs} \alpha$ isoform expressed in whole intestine from 2 week old preweaned compared with the 8 week old postweaned rat (Fig 2B). A similar decline was seen in Gs $\alpha$ isolated from isolated enterocytes (Fig 2C) $(\mathrm{p}<0.05)$.

\section{$C T$ catalysed ADP-ribosylation of membrane} proteins in rat enterocytes

To determine if the two immunodetectable Gso isoforms could serve as substrates for CT in ADP-ribosylation, CT catalysed [ $\left.{ }^{32} \mathrm{P}\right] \mathrm{ADP}$ ribosylation was performed using membrane proteins prepared from isolated enterocytes. CT catalysed the ADP-ribosylation of both the 45000 and $52000 \mathrm{Gs} \alpha$ isoforms. The expression of the large isoform (52000) declined from 2 to 8 weeks of age $(p<0.025)$; however, there was no change in the smaller protein (45000). In accordance with the data examining Gs protein expression (discussed earlier), there was a significant fall in ribosylation activity in enterocytes from 2 weeks old compared with 8 weeks old rats (Fig 3). These experiments

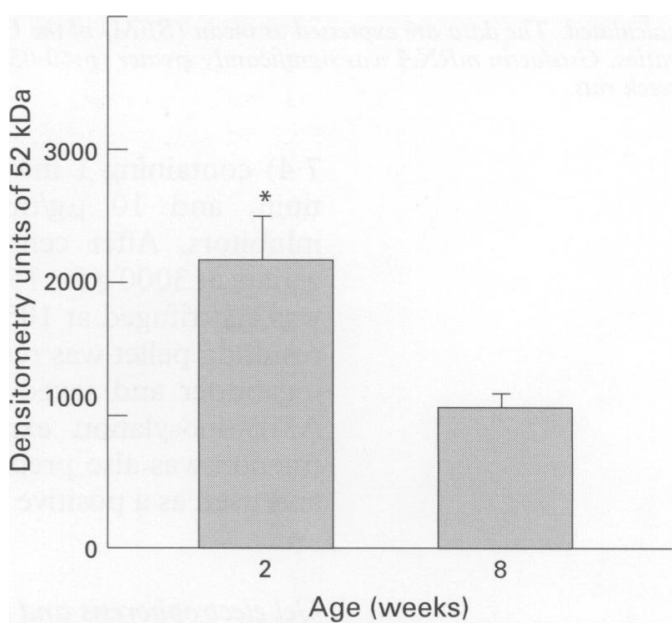

Figure 3: Cholera toxin catalysed $\left.{ }^{32} P\right] A D P$-ribosylation of enterocyte membrane proteins in the pre and postweaned rat. Densitometry analysis of the ribosylated 52000 band and standard deviation of three experiments. The ribosylation reaction was performed using $100 \mu$ membrane, $20 \mu \mathrm{g} / \mathrm{ml}$ activated cholera toxin, $20 \mu \mathrm{M} \mathrm{\beta}^{2} \mathrm{P}$ NAD (20 $000 \mathrm{cpm} / \mathrm{pmol}), 20 \mathrm{mM}$ isoniazid, $1 \mathrm{mM} 3-$ acetylpyridine adenine nucleotide, $10 \mathrm{mM}$ thymidine, 10 $\mathrm{mM}$ thymidine, $10 \mathrm{mM}$ dithiothrietol, $0 \cdot 1 \%$ Triton

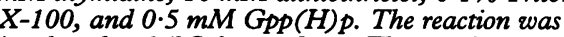
incubated at $25^{\circ} \mathrm{C}$ for one hour. The membrane was recovered and subject to SDS-PAGE on a $10 \%$ gel. * Significant difference at $p<0.05$ level from corresponding value of 8 week old rat. 
therefore show that Gs $\alpha$ mRNA, protein levels, and ribosylation activity are under developmental regulation.

\section{Discussion}

CT induced secretory diarrhoea occurs more commonly in young infants than in older children and adults. ${ }^{311}$ It is the best characterised disease mediated by a Gs $\alpha / c$ AMP signalling pathway. Previous studies from our laboratory have shown an increased sensitivity in the adenylate cyclase response to CT in the small intestine of suckling rats. ${ }^{15}$ This was accompanied by an increased responsiveness in toxin induced fluid secretion. ${ }^{16}$ In this study, we have examined these findings and provide evidence to suggest that the molecular basis for this changed host responsiveness might be related to a developmental variation in Gs $\alpha$ gene expression.

Several lines of evidence show that Gs $\alpha$ gene expression may be modulated by developmental and hormonal regulation as well as by disease states. For example, an age dependent decrease in the expression of the $1.9 \mathrm{~kb}$ Gs $\alpha$ mRNA transcript was noted in rat brain ${ }^{29}$ and rat testes. ${ }^{30}$ Treatment of F9 mouse teratocarcinoma cells with retinoic acid for five days resulted in a 20 -fold increase in steady state levels of a $2.0 \mathrm{~kb}$ Gs $\alpha$ mRNA, accompanied by an increase in the expression of the 45000 and $52000 \mathrm{Gs} \alpha$ polypeptides. ${ }^{31}$ In addition, a decreased Gs $\alpha$ mRNA level was associated with a fall in Gs protein and in adenylate cyclase activity in compensated left ventricular hypertrophy. ${ }^{32}$ In a neuroblastoma $\alpha$ glioma hybrid, NG108-15 cells, the mechanisms of an ethanol induced change in adenylate cyclase entails a decrease in gene expression of $G s \alpha$, resulting in a decrease in the quantity of Gs $\alpha$ mRNA and Gs $\alpha$ protein in those cell membranes exposed longterm to ethanol. ${ }^{33}$

In the small intestine, our results have shown an increased level of Gs $\alpha$ mRNA expression in the suckling compared with the mature rat although the exact degree of decrease varied with the litter examined (Fig 1). A dependence on litter is a feature of a number of developmentally regulated genes. ${ }^{24}$ The 52000 , but not the 45000 , Gs $\alpha$ protein isoform concentration was also significantly greater in suckling compared with post-weaned rats. This was reflected in a reduction of ADP-ribosylation of the $\mathbf{5 2 0 0 0}$ isoform with development although both isoforms were ADP-ribosylated by $\mathrm{CT}$ in vitro.

Under physiological conditions, intestinal Gs $\alpha$ is used by vasoactive intestinal peptide as a signal transducer, coupling the $\beta$-adrenergic receptor to adenylate cyclase. Chastre et al ${ }^{34}$ reported that intestinal cells are more sensitive to a vasoactive intestinal peptide induced adenylate cyclase response in 17 and 19 day old fetuses than in adult rats. They further showed that the difference might result from a developmental variation at the level of vasoactive intestinal peptide receptors.

It is noteworthy that in enterocytes, the catalytic unit of adenylate cyclase is located on the basolateral membrane, ${ }^{7}$ while depending on species, the distribution of the enzyme's regulatory unit is not necessarily restricted to the basolateral membrane. In rat enterocytes, the CT targeted Gs $\alpha$ is found on the basolateral membrane. ${ }^{35}$ In contrast, in the small intestines of rabbits, CT catalyses ADP-ribosylation of Gs $\alpha$ proteins in the microvillus membrane and these proteins then migrate to the basolateral membrane where they activate the catalytic component of adenylate cyclase. ${ }^{3637}$ The basis for this species specific sorting difference of $\mathrm{Gs} \alpha$ proteins in polarised enterocytes is currently unknown.

In summary, this study suggests that a postnatal decline in Gs $\alpha$ gene expression in rat enterocytes may in part contribute to an age dependent difference in adenylate cyclase responsiveness to stimulation by bacterial toxins.

We wish to thank Ms Suzzette McCarron and Ms Sally Burke for their expert typing of this manuscript. We also are indebted to David Schoenfeld, $\mathrm{PhD}$ for statistical advice.

This work was supported by grants from the National Institutes of Health (RO1 HD31852 and RO1 HD12437).

1 Gilman AG. G proteins: transducers of receptor-generated signals. Ann Rev Biochem 1987; 56: 615-49.

2 Kaziro Y, Itoh H, Kozasa T, NaKafuky M, Satoh T. Structure and function of signal-transducing GTP-binding proteins. Ann Rev Biochem 1991; 60: 349-400.

3 Kelly MT. Cholera: a worldwide perspective. Pediatr Infect Dis 1986; 5: 5101-5.

4 Moss J, Vaughan M. ADP-ribosylation of guanyl nucleotide-binding regulatory proteins by bacterial toxins. Adv Enzymnol 1988; 61: 303-79.

5 Janicot M, Fouque F, Desbuquois B. Activation of rat liver adenylate cyclase by cholera toxin requires toxin internalization and processing in endosomes. $7 \mathrm{Biol}$ Chem 1991; 266: 12858-65.

6 Lencer WI, Delp C, Neutra MR, Madara JL. Mechanism of cholera toxin action on a polarized human intestinal epithelial cell line: role of vesicular traffic. $₹$ Cell Biol 1992; 117: 1197-209.

7 Field M, Rad MC, Chang EB. Intestinal electrolyte transport and diarrheal disease. $N$ Engl f Med 1989; 321: 879-83. 8 Anderson MP, Gregory RJ, Thompson S, Souza DW, Paul $\mathrm{S}$, Mulligan RC, et al. Demonstration that CFTR is a chloride channel by alteration of its anion selectivity. Science 1991; 253: 202-5.

9 Dominguez P, Barros F, Lazo PF. The activation of adenyate cyclase from small intestinal epithelium by cholera toxin. Eur F Biochem 1985; 146: 533-8.

10 Hansson GC. Cystic fibrosis and chloride-secreting diarrhoea. Nature 1988; 333: 711 .

$11 \mathrm{Chu}$ SW, Walker WA. Bacterial toxin interaction with the developing intestine: a possible explanation for toxigenic developing intestine: a possible explanation for toxigenic

12 Itoh H, Kozasa T, Nagata S, Nakamura S, Katada T, Ui M, et al. Molecular cloning and sequence determination of cDNAs for $\alpha$ subunits of the guanine nucleotide-binding proteins $\mathrm{G}_{\mathrm{s}}, \mathrm{G}_{\mathrm{i}}$, and $\mathrm{G}_{\mathrm{o}}$ from rat brain. Proc Natl Acad Sci USA 1986; 83: 3776-80.

13 Kozasa $\mathrm{T}$, Itoh $\mathrm{H}$, Tsukamoto $\mathrm{T}$, Kaziro $\mathrm{Y}$. Isolation and characterization of the human Gs $\alpha$ gene. Proc Natl Acad Sci USA 1988; 85: 2081-5.

14 Gill DM, Meren R. ADP-ribosylation of membrane proteins catalyzed by cholera toxin: basis of the activation of adenylate cyclase. Proc Natl Acad Sci USA 1978; 75: $3050-4$.

15 Seo JK, Chu SW, Walker WA. Development of intestinal host defense: an increased sensitivity in the adenylate host defense: an increased sensitivity in the adenylate
cyclase response to cholera toxin in suckling rats. Pediatr Res 1989; 25: 225-7.

$16 \mathrm{Chu}$ SW, Ely IG, Walker WA. Age and cortisone alter host responsiveness to cholera toxin in the developing gut. $\mathrm{Am}$ f Physiol 1989; 256: G220-5.

17 Weiser MM. Intestinal epithelial cell surface membrane glycoprotein synthesis. I. An indicator of cellular differentiation. F Biol Chem 1973; 248: 2536-41.

18 Enoch T, Zinn K, Maniatis T. Activation of the human $\beta-$ interferon gene requires an interferon-inducible factor. Mol Cell Biol 1986; 6: 801-10.

19 Feinburg AP, Vogelstein B. A technique for radioactively labeling DNA restriction endonuclease fragments to high specific activity. Anal Biochem 1984; 137: 266-7.

20 Chirgwin JM, Przybyla AE, MacDonald RJ, Rutter WJ. Isolation of biologically-active ribonucleic acid from sources enriched in ribonuclease. Biochemistry 1979; 18: 5294-9.

21 Ouellette AJ, Cordell B. Accumulation of abundant messenger ribonucleic acids during postnatal development of mouse small intestine. Gastroenterology 1988; 94: 114-21. 
22 Perry RP, LaTorre J, Kelley DE, Greenburg JR. On the lability of poly(a) sequences during extractions of messenger RNA from polyribosomes. Biochem Biophys Acta 1979; 262: $220-6$.

23 Sambrook J, Fritsch EE, Maniatis EF. Molecular cloning. 2nd ed. New York: Cold Spring Harbor Laboratory Press, 2nd ed.

24 Sanderson IR, Ouellette AJ, Carter EA, Harmatz PR Ontogeny of class II MHC mRNA in the mouse intestinal
epithelium is modulated by age of weaning and diet. epithelium is modulated by age of
Gastroenterology 1993; 105: 974-80.

25 Laemmli UK. Cleavage of structural protein during assembly of the head of bacteriophage T4. Nature (London) 1970; 227: 680-5.

26 Towbin H, Staehelin T, Gordon J. Electrophoretic transfer of proteins from polyacrylamide gels to nitrocellulose sheets: procedure and some applications. Proc Natl Acad Sci USA 1979; 76: 4350-4.

27 Oguchi S, Walker WA, Sanderson IR. Insulin-like growth factor binding protein profile secreted by human intestinal epithelial cells varies with polarity. Biochem Biophys Res epithelial cells varies with pola

28 Gill DM, Woolkalis MJ. Cholera toxin-catalyzed [32P]ADP-ribosylation of proteins. Methods Enzymol 1991; 195: 267-80.

29 Duman RS, Saito N, Tallman JF. Development of the $\beta$ adrenergic receptor and $G$ protein messenger RNA in rat brain. Mol Brain Res 1989; 5: 289-96.

30 Haugen TB, Paulssen EJ, Gordeladze JO, Hansson V. A unique mRNA species for the $\alpha$ subunit of $G$ s is present in rat haploid germ cells. Biochem Biophys Res Commun 1990; 168: $91-8$.

31 Chan SDH, Strewler GJ, Nissenson RA. Transcriptional activation of $\mathrm{Gs} \alpha$ expression by retinoic acid and parathyroid hormone-related protein in F9 teratocarcinoma cells. f Biol Chem 1990; 265: 20081-4.

32 Chen L, Vatner ED, Vatner SF, Hittinger L, Homcy CJ. Decreased Gs $\alpha$ mRNA levels accompany the fall in Gs and adenyl cyclase activities in compensated left ventricular hypertrophy: in heart failure, only the impairment of adenylyl cyclase activation progresses. $f$ Clin Invest 1991; 87: 293-8.

33 Mochly-Rosen D, Chang F-H, Cheever L, Kim M, Diamon I, Gordon AS. Chronic ethanol causes heterologous desensitization of receptors by reducing $\alpha$ s messenger RNA. Nature 1988; 333: 848-50.

34 Chastre E, Emami S, Rosselin G, Gespach C. Ontogenic development of vasoactive intestinal peptide receptors in rat intestinal cells and liver. Endocrinology 1987; 121: 2211-21.

35 Pamukcu $R$, Yamashita $R$, Chang EB. Immunological and biochemical identification of GTP-binding protein distribution in rat enterocyte plasma membranes. Gastroenterology 1989; 96: A382.

36 Dominquez P, Velasco G, Barros F, Lazo PS. Intestinal brush border membranes contain regulatory subunits of adenyl cyclase. Proc Natl Acad Sci USA 1987; 84: 6965-9.

37 Longbottom DS, van Heyningen DS. The activation of rabbit intestional adenylate cyclase by cholera toxin. Biochem Biophys Acta 1987; 1014: 289-97. 